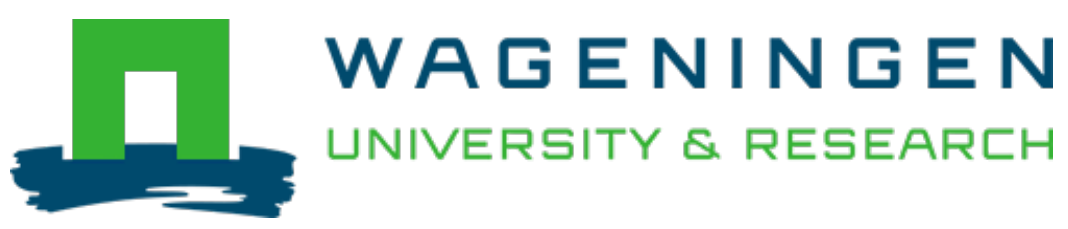

\title{
Detection of peanut allergens in serum : circumventing the inhibitory effect of immunoglobulins
}

\author{
Allergy \\ Koppelman, Stef J.; Witteveen, Michel; JanssenDuijghuijsen, Lonneke; Baumert, Joseph L.; Witkamp, Renger \\ F. et al \\ https://doi.org/10.1111/all.14330
}

This article is made publicly available in the institutional repository of Wageningen University and Research, under the terms of article $25 \mathrm{fa}$ of the Dutch Copyright Act, also known as the Amendment Taverne. This has been done with explicit consent by the author.

Article 25 fa states that the author of a short scientific work funded either wholly or partially by Dutch public funds is entitled to make that work publicly available for no consideration following a reasonable period of time after the work was first published, provided that clear reference is made to the source of the first publication of the work.

This publication is distributed under The Association of Universities in the Netherlands (VSNU) 'Article 25fa implementation' project. In this project research outputs of researchers employed by Dutch Universities that comply with the legal requirements of Article $25 \mathrm{fa}$ of the Dutch Copyright Act are distributed online and free of cost or other barriers in institutional repositories. Research outputs are distributed six months after their first online publication in the original published version and with proper attribution to the source of the original publication.

You are permitted to download and use the publication for personal purposes. All rights remain with the author(s) and / or copyright owner(s) of this work. Any use of the publication or parts of it other than authorised under article $25 \mathrm{fa}$ of the Dutch Copyright act is prohibited. Wageningen University \& Research and the author(s) of this publication shall not be held responsible or liable for any damages resulting from your (re)use of this publication.

For questions regarding the public availability of this article please contact openscience.library@,wur.nl 


\section{Detection of peanut allergens in serum: circumventing the inhibitory effect of immunoglobulins}

To the Editor,

Mose et $\mathrm{al}^{1}$ reopened the discussion on bioavailability of digestion-stable food allergens in human. Their paper elegantly shows that peanut allergen can be detected in serum, minutes to hours following peanut consumption by healthy subjects. Interestingly, different assays show different results. A basophil histamine release (BHR) assay indicated peanut allergen appearing in serum already after about 5-10 minutes, peaking at 1 hour and decreasing again after 4-8 hours, while some remained till 48 hours after ingestion. Using quantitative ELISA, Ara h 6 was detected with essentially the same kinetics as was found with BHR assay, and peak values ranged between 0.05 and $0.25 \mathrm{ng} / \mathrm{mL}$ for different subjects. However, presence of Ara $\mathrm{h} 6$ could not be demonstrated in all subjects. Three different types of quantitative mass spectrometry targeting Ara h 2 peptides appeared not sufficiently sensitive to detect Ara h $2 .{ }^{1}$

Our previous work on detection of Ara h 6 in serum from healthy individuals who ingested peanut showed similar peak levels as those reported by Mose et al, ${ }^{2}$ and we also observed strong variability between subjects. We demonstrated that Ara h 6 can bind to IgG endogenously present in the serum of some individuals. If bound, it can no longer be detected by ELISA. We also showed that a high-IgG titer of an individual was associated with a higher inhibition of ELISA reactivity. ${ }^{2}$ We now report a new approach to circumvent the inhibitory effects of serum-born IgG on detection of Ara $\mathrm{h} 6$ by ELISA.

Binding of immunoglobulins to antigens can be disrupted by heat treatment, such as heating to $62^{\circ} \mathrm{C}^{3}$ or $71^{\circ} \mathrm{C} .^{4}$ Because the protein structure of Ara $\mathrm{h} 6$ is heat stable and not affected by temperatures up to $90^{\circ} \mathrm{C},{ }^{5}$ we hypothesized that a heat treatment step of serum samples would lead to dissociation of the Ara h 6-lgG4 complex, while Ara $\mathrm{h} 6$ would retain its antigenic properties in the ELISA. Also, heat treatment at a temperature of $75^{\circ} \mathrm{C}$ or higher will lead to irreversible denaturation of $\mathrm{IgG},{ }^{4}$ preventing re-association with Ara $\mathrm{h}$ 6 after cooling to ambient temperature. Two heating protocols were performed in a thermocycler with temperature changes at $2{ }^{\circ} \mathrm{C} / \mathrm{s}$ (20 minutes at $75^{\circ} \mathrm{C}$ or 40 minutes at $65^{\circ} \mathrm{C}$, followed by 20 minutes at $85^{\circ} \mathrm{C}$ ). Figure 1 shows the detection of Ara h 6 by 2-sided (sandwich) ELISA in sera of healthy subjects that had consumed $100 \mathrm{~g}$ of

(A)

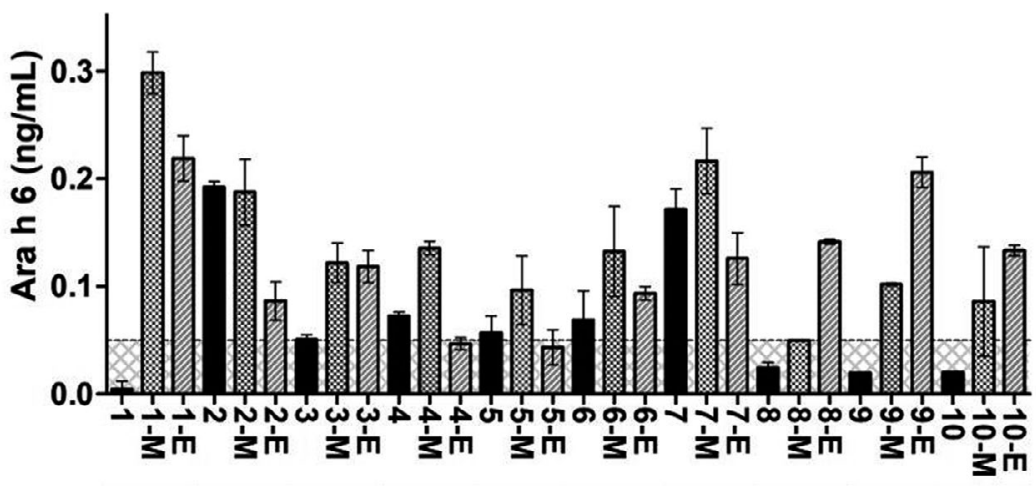

(B) Subject \#
Ara h 6-IgG4 Titre

\begin{tabular}{|c|c|c|c|c|c|c|c|c|c|}
\hline 1 & 2 & 3 & 4 & 5 & 6 & 7 & 8 & 9 & 10 \\
$>1280$ & N.D. & N.D. & 44 & 96 & N.D. & N.D. & $>1280$ & $>1280$ & $>1280$ \\
\hline
\end{tabular}

FIGURE 1 Detection of Ara h 6 in serum by ELISA (sandwich format); effect of heat treatment and Ara h 6-specific IgG4 titer. A, Detection of Ara h 6 in 4-fold diluted sera of healthy subjects 1-10 two hours after consuming $100 \mathrm{~g}$ peanut. Black bars: no treatment; blocked bars: mildly heat-treated $\left(20 \mathrm{~min}, 75^{\circ} \mathrm{C}\right.$, coded "M"); striped bars: extensively heat-treated $\left(40 \mathrm{~min}, 65^{\circ} \mathrm{C}\right.$ plus $20 \mathrm{~min}, 85^{\circ} \mathrm{C}, \mathrm{coded}$ "E"). Striped line: lower limit of quantification (defined as blanc $+10 \times$ SD of the blanc). B, Ara h 6-specific lgG4 titer, defined as the dilution of serum that resulted in an absorbance of two times the blanc, calculated by interpolation, as determined in direct IgG4 ELISA (Ara h 6 coat, serum incubation, IgG4 detection with labeled anti-IgG4 antibodies [ab99817, Abcam]), as described by Janssen Duijghuijsen. ${ }^{2}$ N.D.: non-detectable (at the least possible dilution of 5-fold IgG4 was not detected). Ethics: METC-WU 15/34; NTR5655, conducted in accordance with Declaration of Helsinki 
peanuts 2 hours before blood withdrawal. ${ }^{2}$ Clearly, heat treatment of sera increases the amount of detectable Ara h 6 (Figure 1A). For some sera, a more extensive heat treatment was needed to release the bound Ara h 6. Differences in effect of heat treatment protocols between the various sera may be due to the characteristics of a subject's IgG to bind Ara h 6. By applying the heat treatment step, Ara $\mathrm{h} 6$ can be detected in serum samples that were negative for Ara $\mathrm{h}$ 6 at earlier testing. ${ }^{2}$ Heat treatment had less pronounced effect on sera obtained from subjects with low- or non-detectable lgG4 to Ara h 6 (Ara h 6-specific IgG4 titer of subjects are shown in Figure 1B).

Apart from being useful for detection by ELISA, this heat treatment may also improve detectability by other methods such as mass spectrometry. A common sample preparation step for mass spectrometry is removing of high-abundance proteins from serum such as serum albumins, and this most likely will remove IgG too. Ara $\mathrm{h}$ 6 , or other food proteins, bound to IgG will be removed too, leading to underestimation. The heat treatment protocols we present here may circumvent that. We hypothesize that such procedure may also work for non-heat-stable proteins, because commonly applied quantitative mass spectrometry approaches target peptides rather than intact proteins, and the effect of heat treatment on recovery of peptides in such workflow is expected to be limited.

We conclude that heat treatment of serum samples enables recovery of heat-stable, IgG-bound food allergens. Performed in standard laboratory thermocycler (eg PCR apparatus), this pre-treatment step is easy to implement, requires only small volumes of sample, and may lead to more reliable detection of serum allergen levels.

\section{KEYWORDS}

allergens, food allergy, IgE, IgG4, peanut

\section{ACKNOWLEDGMENTS}

The authors thank Tom van der Linden for his support in testing IgG4 levels in serum samples.

\section{CONFLICTS OF INTEREST}

Michel Witteveen, Lonneke Janssen Duijghuijsen, Renger Witkamp, and Klaske van Norren have nothing to disclose. Stef Koppelman reports financial interest in DBV Technologies, outside the submitted work. Joseph Baumert reports personal fees from DBV Technologies and personal fees from Neogen Corporation, outside the submitted work.

Stef J. Koppelman ${ }^{1}$

Michel Witteveen ${ }^{2}$
Lonneke JanssenDuijghuijsen ${ }^{2,3}$

Joseph L. Baumert ${ }^{1}$

Renger F. Witkamp ${ }^{2}$ Klaske van Norren ${ }^{2}$ iD

${ }^{1}$ Food Allergy Research and Resource Program, Department of Food Science \& Technology, University of Nebraska, Lincoln, NE,

${ }^{2}$ Nutritional Biology, Department of Human Nutrition and Health, Wageningen University and Research, Wageningen, The Netherlands

${ }^{3}$ Human and Animal Physiology, Wageningen University and Research, Wageningen, The Netherlands

Correspondence

Stef J. Koppelman, Food Allergy Research and Resource Program, Department of Food Science \& Technology, University of Nebraska, 279 Food Innovation Center, Lincoln, NE 68588-6207, USA. Email: FARRP@UNL.edu

\section{ORCID}

Stef J. Koppelman iD https://orcid.org/0000-0001-7995-1754

Klaske van Norren (iD https://orcid.org/0000-0002-6281-9455

\section{REFERENCES}

1. Mose AP, Mortz E, Stahl Skov P, et al. The quest for ingested peanut protein in human serum. Allergy. 2020;75:1721-1729.

2. Janssen Duijghuijsen LM, Wichers HJ, van Norren K, et al. Detection of peanut allergen in human blood after consumption of peanuts is skewed by endogenous immunoglobulins. J Immunol Methods. 2017;440:52-57.

3. Xu W, Sank M, Cummings J, et al. Bead-extraction and heat-dissociation (BEHD): a novel way to overcome drug and matrix interference in immunogenicity testing. J Immunol Methods. 2018;462:34-41.

4. Vermeer AW, Norde W. The thermal stability of immunoglobulin: unfolding and aggregation of a multi-domain protein. Biophys $\mathrm{J}$. 2000;78(1):394-404.

5. Lehmann K, Schweimer K, Reese G, et al. Structure and stability of $2 \mathrm{~S}$ albumin-type peanut allergens: implications for the severity of peanut allergic reactions. Biochem J. 2006;395(3):463-472.

\section{SUPPORTING INFORMATION}

Additional supporting information may be found online in the Supporting Information section. 